\title{
Fatal splenic sequestration crisis in adult sickle cell-beta thalassaemia
}

\author{
F. van Rhee, M. Balsitis' and E.A. French \\ Departments of Haematology and ${ }^{1}$ Histopathology, University Hospital, Queen's Medical Centre, \\ Nottingham, UK
}

Summary: Fatal acute splenic sequestration crisis in an adult patient with sickle cell-beta ${ }^{+}$ thalassaemia is described. To our knowledge fatal splenic sequestration in adult sickle cell-beta thalassaemia has not been previously reported.

\section{Introduction}

Sickle cell-beta thalassaemia is a heterogeneous disorder with a variable clinical expression ranging from a symptomless state to a condition indistinguishable from homozygous sickle cell anaemia. Sickle cell-beta ${ }^{+}$thalassaemia is generally thought to represent the milder end of the spectrum of sickle cell syndromes. We describe an adult case with fatal acute splenic sequestration (ASS) illustrating that sickle cell-beta thalassaemia may run an unexpected severe clinical course.

\section{Case report}

A 32 year old man of Jamaican ancestry was admitted with generalized bone pains. He was known to have sickle cell-beta ${ }^{+}$thalassaemia for which he had required hospital admission for sickle cell crisis only once previously. Physical examination was unremarkable and both liver and spleen were not palpable. Laboratory investigations showed haemoglobin $(\mathrm{Hb}) 12.1 \mathrm{~g} / \mathrm{dl}(\mathrm{MCV}$ 82fl, MCH $26.3 \mathrm{pg}$ ), white cell count (WBC) $6.9 \times 10^{9} / 1$ (neutrophils $78.3 \%$ ), platelet count $146 \times 10^{9} / 1$, reticulocyte count $0.1 \%$. The blood film showed target cells and mild hypochromia but no sickle cells were present. $\mathrm{Hb}$ quantitation by standard methods revealed: $\mathrm{HbA} 19 \%, \mathrm{HbF} 4.7 \% \mathrm{HbA} 2$ $9.2 \%$ and $\mathrm{HbS} 67.1 \%$. Urea and electrolytes, liver function tests and blood gases were all normal.

Management included intravenous fluids,

Correspondence: F. van Rhee, M.R.C.P., Department of Haematology, John Radcliffe Hospital, Headington, Oxford OX3 9DU, UK

Accepted: 4 April 1991 pethidine and amoxycillin which produced a considerable improvement in his symptoms by the next day. On the third day of admission his condition deteriorated in a matter of hours. He became pyrexial (temperature $38.5^{\circ} \mathrm{C}$ ) and confused, with a fluctuating consciousness level. Tachycardia, hypotension and tachypnoea indicated that circulatory failure had developed. A chest X-ray revealed no evidence of sickle chest syndrome and blood and urine cultures grew no organisms. Antemortem hepatosplenomegaly was not noted. He sustained a grand mal convulsion followed shortly after by cardiac arrest and attempts at resuscitation were unsuccessful. A blood count obtained just before death showed a marked drop in his $\mathrm{Hb}$ to $4.5 \mathrm{~g} / \mathrm{dl}$. The WBC was $7.5 \times 10^{9} / 1$ with a normoblast count of $17 / 100 \mathrm{WBC}$ and platelet count $18 \times 10^{9} / 1$; the blood film showed sickled cells and schistocytes. Coagulation studies were abnormal: prothrombin time 33 seconds (15 seconds), activated partial thromboplastin time 59 seconds (51 seconds), thrombin clotting time 25 seconds (18 seconds). Methaemalbumin and free haemoglobin were found in the serum.

The most striking finding at post-mortem was that of marked splenomegaly. The spleen was firm, deeply plum coloured and weighed $750 \mathrm{~g}$ (normal $150 \mathrm{~g}$ ). Microscopy confirmed intense congestion by sickle shaped red blood cells, obscuring the normal structure of the splenic parenchyma (Figure 1). The liver was slightly enlarged at $1800 \mathrm{~g}$ (normal $1500 \mathrm{~g}$ ) and microscopy showed marked sinusoidal congestion. The brain showed hypoxic neuronal loss in many cortical areas due to occlusion of small cerebral vessels by sickled red cells. The bone marrow showed active haemopoiesis with no evidence of aplasia. Extensive red cell sickling in the bone marrow sinusoids was noted. 


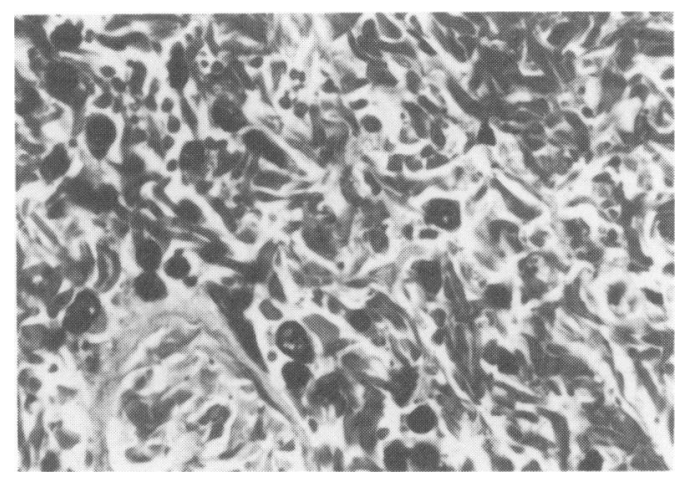

Figure 1 The splenic sinusoids show marked distension by sickled red cells. A thin walled vein (lower left) also contains sickled red cells $(H \& E \times 1320)$.

\section{Discussion}

Sickle cell-beta ${ }^{+}$thalassaemia is due to the interaction between $\mathrm{HbS}$ and the mild Negro form of beta $^{+}$thalassaemia resulting in a $\mathrm{HbA}$ level of $18-30 \%$ which has an inhibitory effect on red cell sickling. It runs a milder course than sickle cell anaemia with a lower incidence of anaemia, vasoocclusive episodes and leg ulcers. Nearly half of the patients are asymptomatic and the diagnosis is frequently made incidentally on population screening. ${ }^{1}$ However, it is important to emphasize that serious complications may occur unexpectedly as is shown by our patient, who developed fatal ASS.

ASS is characterized by sequestration of red cells in the spleen causing anaemia and hypovolaemia with circulatory failure in the presence of a cellular marrow. The marked fall in haemoglobin in this patient may have been aggravated by intravascular haemolysis. Although the reticulocyte count was not elevated, the presence of $17 \%$ normoblasts in the peripheral blood indicated an actively responding marrow, whilst bone marrow histology excluded aplastic crisis. Cerebral hypoxia due to intravascular sickling precipitated convulsions.

ASS is most common in children between 6 and
12 months with homozygous sickle-cell anaemia. ${ }^{2}$ Reports in adults are few, for splenic red cell sequestration can only occur if the spleen is not fully fibrosed, but still distensible. The presence of splenomegaly in adult patients with sickling disorders is therefore of clinical importance. Splenomegaly in adult homozygous sickle cell anaemia is generally thought to be rare but an incidence of $9 \%$ has been described in a Jamaican population. ${ }^{3}$ Reduction in splenic size with malaria prophylaxis suggests that malaria may contribute to splenomegaly in sickle cell anaemia in endemic areas. ${ }^{4}$ Clinical splenomegaly in sickle cell-HbC disease is over $50 \%$ in most series. ${ }^{5}$ West African women in the third trimester of pregnancy with homozygous sickle cell anaemia or sickle cell-HbC disease are at particular risk of developing splenic sequestration. ${ }^{6}$ An enlarged and probably distensible spleen is present in $52 \%$ of patients with sickle cell-beta thalassaemia and since splenomegaly is not related to age ASS may occur in any age group. ${ }^{\prime}$

The pathogenesis of ASS remains yet to be elucidated but it has been suggested that an acute obstruction of the venous outflow of the spleen due to sickling is the initiating event. Experimental ligation of the splenic vein in animals may produce a similar picture. ${ }^{7}$ No specific symptoms have been associated with ASS. A sudden onset and rapids clinical deterioration are predictive of a poor outcome with high mortality. ${ }^{2}$ The only effective treatment is transfusion of red cells, directly or by partial exchange. Transfusion improves the rheology of the blood and may restore venous outflow of the spleen with resolution of splenic sequestration. Splenectomy is indicated if crises recur or hypersplenism supervenes.

\section{Acknowledgements}

We thank Dr Margaret Stewart for allowing us to use the post-mortem material and Mr Bill Brackenbury for photography.

\section{References}

1. Serjeant, G.R., Ashcroft, T.M., Serjeant, B.E. \& Molner, F.B. The clinical features of sickle-cell beta thalassaemia in Jamaica. Br J Haematol 1973, 24: 19-30.

2. Topley, J.M., Rogers, D.W., Stevens, M.C.G. \& Serjeant, G.R. Acute splenic sequestration and hypersplenism in the first five years in homozygous sickle cell disease. Arch Dis Child 1981, 56: 765-769.

3. Serjeant, G.R. Irreversibly sickled cells and splenomegaly in sickle cell anaemia. Br J Haematol 1970, 19: 635-641.

4. Hendrickse, R.G. The effect of malaria chemoprofylaxis in splenic size in sickle cell anemia. In: Jonxis, J.H.P. (ed.). Abnormal Haemoglobins in Africa. Blackwell Scientific Publ., Oxford, 1965, pp. 445-449.

5. Serjeant, G.R. Sickle Cell Disease. Oxford Medical Publications, Oxford, 1985, pp. 302-303.

6. Hendrickse, J.P. de V., Harrison, K.A., Watson-Williams, E.J., Luzatto, L. \& Ajabor, L.N. Pregnancy in homozygous sickle cell anaemia. J Obstet Gynaecol Br Commonw 1972, 79: 396-409.

7. Altman, K.I., Watman, R.N. \& Solomon, K. Surgically induced splenogenic anaemia in the rabbit. Nature 1951, 168: 827. 